\title{
MODEL PENGUKURAN KINERJA INTELLECTUAL CAPITAL DENGAN IB-VAIC DI PERBANKAN SYARIAH
}

\author{
Ihyaul Ulum \\ Program Doktor Ilmu Ekonomi Universitas Diponegoro Semarang \\ E-mail: mas_ulum@yahoo.com
}

\begin{abstract}
The aim of this study is to develop a measurement of intellectual capital performance of Indonesian syariab banking by modifying the Pulic's model that popular with the name of VAIC (value added intellectual coefficient). This study was done by documentation and focus group discussion with some financial accounting experts and public accountants. The result show that the main formula to measure IC performance of syariah banking is not too different with Pulic model, it was: $i B-V A I C^{T M}=i B-V A C A+I B-$ $V A H U+i B-S T V A$. The different one is the accounts to develop VA. VA in Pulic model was constructed by total revenue, while in iB-VAIC, VA was constructed from syariah activities.
\end{abstract}

Keywords: iB-VAIC, Syariah Banking, Intellectual Capital

\begin{abstract}
Abstrak
Tujuan penelitian ini adalab untuk mengembangkan suatu ukuran kinerja intellectual capital (IC) untuk perbankan syariab di Indonesia dengan memodifikasi model Pulic yang populer dengan sebutan VAIC (value added intellectual coefficient). Penelitian ini dilakukan melalui dokumentasi dan FGD (focus group discussion) bersama para pakar di bidang akuntansi keuangan dan akuntan publik. Hasil penelitian menunjukkan babwa rumus utama untuk mengukur kinerja IC perbankan syariah tidak jaub berbeda dengan model Pulic, yaitu: iB$V A I C^{T M}=i B-V A C A+I B-V A H U+i B-S T V A$. Perbedaannya terletak pada akun-akun yang digunakan untuk mengembangkan rumus VA. VA dalam model Pulic dikonstruksi dari total pendapatan, sementara dalam iB-VAIC, VA dikonstruksi dari aktivitas-aktivitas syariah.
\end{abstract}

Kata kunci: iB-VAIC, Perbankan Syariah, Intellectual Capital. 


\section{Pendahuluan}

Intellectual capital (IC) adalah kajian penelitian baru yang mendapatkan perhatian cukup besar dari para ahli di berbagai disiplin seiring dengan pertumbuhan ekonomi yang berbasis pada pengetahuan (knowledge-based economy) (Ståhle et al. 2011;541). Dari sisi akuntansi, sejumlah penelitian telah dilakukan di berbagai negara untuk mengkaji bagaimana metode untuk mengidentifikasi, mengukur, melaporkan dan menyajikannya dalam laporan perusahaan. Berbagai metode juga telah coba ditawarkan, salah satunya adalah VAIC ${ }^{\text {тм }}$ (value added intellectual coefficient).

VAIC $^{\text {TM }}$ dikonstruksi oleh Pulic (2000) untuk menilai kinerja IC pada perusahaan konvensional (private sector, profit motive, non syariah). Akun-akun yang digunakan dalam menghitung kinerja IC dengan VAIC ${ }^{\mathrm{TM}}$ adalah akun-akun yang lazim pada perusahaan konvensional. Sejauh ini, belum ada instrumen (sejenis VAIC ${ }^{\mathrm{TM}}$ ) yang dapat digunakan untuk menilai kinerja IC perbankan syariah. Sementara di Indonesia, perkembangan perbankan syariah cukup signifikan. Sepanjang tahun 2012 (per Oktober) perbankan syariah tumbuh dengan 37\% sehingga total asetnya menjadi Rp 174,09 triliun. Pembiayaan telah mencapai 135,58 triliun (40,06\%, yoy) dan penghimpunan dana menjadi Rp 134,45 triliun (32,06\%). Dari sisi kelembagaan, jumlah bank yang melakukan kegiatan usaha syariah meningkat seiring dengan munculnya pemain-pemain baru. Sampai akhir 2012, terdapat 11 Bank Umum Syariah (BUS) dan 24 unit usaha syariah (UUS) dengan 508 Kantor Cabang. Jumlah kantor pelayanan (Kantor Kas, Kantor Kas Pembantu) sampai akhir 2012 mencapai 2.188.

Model penilaian kinerja IC untuk perbankan syariah ini (yang akan diberi nama iB-VAIC - dibaca Islamic banking VAIC) penting untuk dihasilkan sebagai modifikasi dari model yang telah ada, yaitu Value Added Intellectual Coefficient-VAIC ${ }^{\mathrm{TM}}$. VAIC ${ }^{\mathrm{TM}}$ didesain untuk mengukur kinerja IC perusahaan-perusahaan dengan jenis transaksi yang umum. Sementara perbankan syariah memiliki jenis transaksinya sendiri yang relatif berbeda dari perbankan umum/konvensional.

Model pengukuran kinerja IC untuk perbankan syariah (iBVAIC) ini menjadi penting untuk dihasilkan setidaknya karena dua alasan: 
Pertama, industri perbankan merupakan salah satu dari 4 industri yang merupakan IC intencive industry sector (Firer \& Williams, 2003;353). Selain itu, dari aspek intelektual, secara keseluruhan karyawan di sektor perbankan lebih homogen dibandingkan dengan sektor ekonomi lainnya (Kubo dan Saka, 2002: 265).

Kedua,hasil penelitian di berbagai negara termasuk di Indonesia, menunjukkan bahwa IC memiliki peran dalam menggerakkan nilai perusahaan (firm's value). IC berpengaruh positif terhadap kinerja keuangan perusahaan - yang merupakan ukuran jangka pendek dan yang paling mudah dilihat, baik pada masa kini maupun di masa yang akan datang. Artinya, IC dapat pula digunakan dalam memprediksi kinerja keuangan perusahaan (lihat misalnya: Chen et al., 2005, Tan et al., 2007 Ulum 2008a, Wang 2011, Kamal et al., 2011; Ahmad \& Mushraf, 2011; Salman et al., 2012; Latif et al., 2012).

Berdasarkan uraian tersebut di atas, maka penelitian ini dirancang untuk menjawab masalah tentang bagaimana model atau metode untuk menilai kinerja IC perbankan syariah di Indonesia.

\section{Teori tentang Intellectual Capital}

Ketertarikan akan IC bermula ketika Tom Stewart, pada Juni 1991, menulis sebuah artikel ("Brain Power - How Intellectual Capital Is Becoming America's Most Valuable Asset'), yang mengantar IC kepada agenda manajemen. Tabel 1 meringkas kronologi beberapa kontribusi signifikan terhadap pengidentifikasian, pengukuran dan pelaporan IC.

Tabel: 1

Kronologi Kontribusi Signifikan terhadap Pengidentifikasian, Pengukuran dan Pelaporan IC

\begin{tabular}{ll}
\hline \multicolumn{1}{c}{ Periode } & \multicolumn{1}{c}{ Perkembangan } \\
\hline Awal 1980-an & $\begin{array}{l}\text { Muncul pemahaman umum tentang Intangible value } \\
\text { (biasanya disebut "goodwill") }\end{array}$ \\
Pertengahan & $\begin{array}{l}\text { Era informasi (information age) memegang peranan, } \\
\text { dan selisih (gap) antara nilai buku dan nilai pasar }\end{array}$ \\
1980-an & $\begin{array}{l}\text { semakin tampak jelas di beberapa perusahaan. } \\
\end{array}$
\end{tabular}


Periode

Perkembangan

Akhir 1980-an Awal usaha para konsultan (praktisi) untuk membangun laporan/akun yang mengukur intellectual capital (Sveiby, 1988).

Awal 1990-an Prakarsa secara sistematis untuk mengukur dan melaporkan persediaan perusahaan atas intellectual capital kepada pihak eksternal (misalnya: Celemi and Skandia; SCSI, 1995)

Padan tahun 1990, Skandia AFS menugaskan Leif Edvinsson sebagai "Direktur intellectual capital". Hal ini adalah untuk kali pertama bahwa tugas pengelolaan intellectual capital diangkat pada posisi formal dan mendapatkan legitimasi perusahaan.

Kaplan dan Norton memperkenalkan konsep tentang balanced scorecard (1992).

Pertengahan Nonaka dan Takeuchi (1995) mempresentasikan 1990-an karya yang sangat berpengaruh terhadap "penciptaan pengetahuan perusahaan". Meskipun buku ini berkonsentrasi pada 'knowledge', pembedaan antara pengetahuan dan intellectual capital dalam buku ini cukup menunjukkan bahwa mereka fokus pada intellectual capital.

Pada tahun 1994, suplemen laporan tahunan Skandia dihasilkan. Suplemen ini fokus pada penyajian dan penilaian Persediaan perusahaan atas intellectual capital. Visualisasi IC menarik minat perusahaan lain untuk mengikuti petunjuk Skandia.

Sensasi lainnya terjadi pada tahun 1995 ketika Celemi menggunakan knowledge audit untuk menawarkan suatu taksiran detail atas pernyataan intellectual capitalnya.

Para pioner intellectual capital mempublikasikan bukubuku laris dengan topik IC (Kaplan dan Norton, 1996; Edvinsson and Malone, 1997; Sveiby, 1997). Karya Edvinsson and Malone lebih banyak mengupas tentang proses dan 'bagaimana' pengukuran IC.

Akhir 1990-an Intellectual capital menjadi topik populer dengan konferensi para peneliti dan akademisi, working paper, dan publikasi lainnya menemukan audien. 


\begin{tabular}{cl}
\hline Periode & \multicolumn{1}{c}{ Perkembangan } \\
\hline & Peningkatan jumlah proyek-proyek besar (misalnya \\
the MERITUM project; Danish; Stockholm) yang & diselenggarakan dengan tujuan, antara lain, untuk \\
& memperkenalkan beberapa penelitian tentang \\
& intellectual capital. \\
& Pada tahun 1999, OECD menyelenggarakan simposium \\
internasional tentang intellectual capital di Amsterdam.
\end{tabular}

Stewart mendefinisikan dalam artikelnya IC adalah "The sum of everything everybody in your company knows that gives you a competitive edge in the market place. It is intellectual material knowledge, information, intellectual property, experience - that can be put to use to create wealth". Brooking (1996: 34) misalnya mendefinisikan IC sebagai "the term given to the combined intangible assets of market, intellectual property, human-centred and infrastructure - which enable the company to function". Sedangkan Roos et al. (1997;76) menyatakan bahwa: "IC includes all the processes and the assets which are not normally shown on the balance-sheet and all the intangible assets (trademarks, patent and brands) which modern accounting methods consider...". Adapaun menurut Bontis (1998;69) mendefinisikan bahwa: "IC is elusive, but once it is discovered and exploited, it may provide an organisation with a new resource-base from which to compete and win"

Salah satu definisi IC yang banyak digunakan adalah yang ditawarkan oleh Organisation for Economic Co-operation and Development (OECD, 1999) yang menjelaskan IC sebagai nilai ekonomi dari dua kategori aset tak berwujud: (1) organisational (structural) capital; dan (2) human capital. 
Tabel: 2

Perbandingan Konsep IC Menurut Beberapa Peneliti

\begin{tabular}{|c|c|c|c|}
\hline Brooking (UK) & Roos (UK) & Stewart (USA) & Bontis (Kanada) \\
\hline $\begin{array}{l}\text { Human-centered } \\
\text { Skills, abilities and } \\
\text { expertise, problem } \\
\text { solving abilities } \\
\text { and leadership styles }\end{array}$ & $\begin{array}{l}\text { Human capital } \\
\text { Competence, } \\
\text { attitude, and } \\
\text { intellectual agility }\end{array}$ & $\begin{array}{l}\text { Human capital } \\
\text { Employees are an } \\
\text { organization's most } \\
\text { important asset }\end{array}$ & $\begin{array}{l}\text { Human capital } \\
\text { The individual level } \\
\text { knowledge that each } \\
\text { employee possesses }\end{array}$ \\
\hline $\begin{array}{l}\text { Infrastructure } \\
\text { assets }\end{array}$ & $\begin{array}{l}\text { Orgnistional } \\
\text { capital }\end{array}$ & Structural capital & Structural capital \\
\hline $\begin{array}{l}\text { All the technologies, } \\
\text { process and } \\
\text { methodologies that } \\
\text { enable company to } \\
\text { function }\end{array}$ & $\begin{array}{l}\text { All organizational, } \\
\text { innovation, processes, } \\
\text { intellectual property, } \\
\text { and cultural assets }\end{array}$ & $\begin{array}{l}\text { Knowledge } \\
\text { s,embedded in } \\
\text { information } \\
\text { technology }\end{array}$ & $\begin{array}{l}\text { Non-human assets } \\
\text { or organizational } \\
\text { capabilities used } \\
\text { to meet market } \\
\text { requirements }\end{array}$ \\
\hline $\begin{array}{l}\text { Intellectual } \\
\text { property }\end{array}$ & $\begin{array}{l}\text { Renewal and } \\
\text { development }\end{array}$ & Structural capital & $\begin{array}{l}\text { Intellectual } \\
\text { property }\end{array}$ \\
\hline $\begin{array}{l}\text { Know-how, } \\
\text { trademarks and } \\
\text { patents }\end{array}$ & $\begin{array}{l}\text { capital } \\
\text { New patents and } \\
\text { training efforts }\end{array}$ & $\begin{array}{l}\text { All patents, plans anc } \\
\text { trademarks }\end{array}$ & $\begin{array}{l}\text { d Unlike, IC, IP is a } \\
\text { protected asset and } \\
\text { has a legal definition }\end{array}$ \\
\hline $\begin{array}{l}\text { Market assets } \\
\text { Brands, customers, } \\
\text { customer loyalty and } \\
\text { distribution channels }\end{array}$ & $\begin{array}{l}\text { Relational capital } \\
\text { Relationship which } \\
\text { include internal and } \\
\text { external stakeholders }\end{array}$ & $\begin{array}{l}\text { Customer capital } \\
\text { Market information } \\
\text { used to capture and } \\
\text { retain customers }\end{array}$ & $\begin{array}{l}\text { Relational capital } \\
\text { Customer capital } \\
\text { is only one feature } \\
\text { of the knowledge } \\
\text { embedded in } \\
\text { organizational } \\
\text { relationships }\end{array}$ \\
\hline
\end{tabular}

Sumber : Bontis et al. (2000;92)

The International Federation of Accountan - IFAC (1998) mengklasifikasikan IC menjadi tiga kategori, yaitu Organizational Capital, Relational Capital, dan Human Capital. Organizational Capital meliputi intellectual property dan infrastructure assets. Table 3 menyajikan secara lebih detil tentang klasifikasi tersebut. 
Table: 3

Klasifikasi Intellectual Capital menurut IFAC

\begin{tabular}{|c|c|c|}
\hline Organizational Capital & Relational Capital & Human Capital \\
\hline $\begin{array}{l}\text { Intellectual Property: } \\
\text { - Patents } \\
\text { - Copyrights } \\
\text { - Design rights } \\
\text { - Trade secret } \\
\text { - Trademarks } \\
\text { - Service marks } \\
\text { Infrastructure Assets: } \\
\text { - Management philosophy } \\
\text { - Corporate culture } \\
\text { - Management processes } \\
\text { - Information systems } \\
\text { - Networking systems } \\
\text { - Financial relations }\end{array}$ & $\begin{array}{l}\text { - Brands } \\
\text { - Customers } \\
\text { - Customer loyalty } \\
\text { - Backlog orders } \\
\text { - Company names } \\
\text { - Distribution channels } \\
\text { - Business collaborations } \\
\text { - Licensing agreements } \\
\text { - Favourable contracts } \\
\text { - Franchising agreements }\end{array}$ & $\begin{array}{l}\text { - Know-how } \\
\text { - Education } \\
\text { - Vocational qualification } \\
\text { - Work-related } \\
\text { knowledge } \\
\text { - Work-related } \\
\text { competencies } \\
\text { - Entrepreneurial } \\
\text { spirit, innovativeness, } \\
\text { proactive and reactive } \\
\text { abilities, changeability } \\
\text { - Psychometric valuation }\end{array}$ \\
\hline
\end{tabular}

Sumber: IFAC, 1998

Bontis et al. (2000: 87) menyatakan bahwa secara umum, para peneliti mengidentifikasi tiga konstruk utama dari IC, yaitu: buman capital (HC), structural capital (SC), dan customer capital (CC). Menurut Bontis et al. (2000: 90), secara sederhana HC merepresentasikan individual knowledge stock suatu organisasi yang direpresentasikan oleh karyawannya. HC merupakan kombinasi dari genetic inheritance; education; experience, and attitude tentang kehidupan dan bisnis.

Lebih lanjut Bontis et al. (2000: 90) menyebutkan bahwa SC meliputi seluruh non-human storehouses of knowledge dalam organisasi. Termasuk dalam hal ini adalah database, organisational charts, process manuals, strategies, routines dan segala hal yang membuat nilai perusahaan lebih besar daripada nilai materialnya. Sedangkan tema utama dari CC adalah pengetahuan yang melekat dalam marketing channels dan customer relationship dimana suatu organisasi mengembangkannya melalui jalannya bisnis (Bontis et al., 2000: 91). 


\section{Value Added Intellectual Coefficient (VAIC ${ }^{\mathrm{TM}}$ )}

Hal terpenting dalam manajemen di abad ke-20 adalah peningkatan hingga 50 kali lipat produktivitas pekerja manual dalam memproduksi. Kontribusi penting manajemen yang harus dibuat di abad ke-21 adalah dengan cara yang sama meningkatkan produktivitas pekerjaan pengetahuan (knowledge work) dan pekerja berpengetahuan (knowledge workers). Aset yang paling berharga bagi perusahaan di abad ke-20 adalah peralatan produksinya. Menurut Peter Drucker, aset yang paling berharga institusi di abad ke-21 adalah pekerja berpengetahuan (knowledge workers) dan produkvitasnya (Pulic, 2000).

Metode value added intellectual coefficient (VAIC ${ }^{\mathrm{TM}}$ ) dikembangkan oleh Pulic pada tahun 1997 yang didesain untuk menyajikan informasi tentang value creation efficiency dari aset berwujud (tangible asset) dan aset tidak berwujud (intangible assets) yang dimiliki perusahaan. VAIC ${ }^{\mathrm{TM}}$ merupakan instrumen untuk mengukur kinerja intellectual capital perusahaan. Pendekatan ini relatif mudah dan sangat mungkin untuk dilakukan, karena dikonstruksi dari akun-akun dalam laporan keuangan perusahaan (neraca, laba rugi) (Ulum 2009b: 111).

Metode ini dimulai dengan kemampuan perusahaan untuk menciptakan value added (VA). Value added adalah indikator paling objektif untuk menilai keberhasilan bisnis dan menunjukkan kemampuan perusahaan dalam penciptaan nilai (value creation). VA dihitung sebagai selisih antara output dan input.

Output (OUT) merepresentasikan revenue dan mencakup seluruh produk dan jasa yang dijual di pasar, sedangkan input (IN) mencakup seluruh beban yang digunakan dalam memperoleh revenue. Hal penting dalam metode ini adalah bahwa beban karyawan (labour expenses) tidak termasuk dalam IN. Karena peran aktifnya dalam proses value creation, intellectual potential (yang direpresentasikan dengan labour expenses) tidak dihitung sebagai biaya (cost) dan tidak masuk dalam komponen IN. Karena itu, aspek kunci dalam metode Pulic adalah memperlakukan tenaga kerja sebagai entitas penciptaan nilai (value creating entity). 
VA dipengaruhi oleh efisiensi dari Human Capital (HC) dan Structural Capital (SC). Hubungan lainnya dari VA adalah capital employed (CE), yang dalam hal ini dilabeli dengan VACA. VACA adalah indikator untuk VA yang diciptakan oleh satu unit dari physical capital.

Pulic (2000) mengasumsikan bahwa jika 1 unit dari CE menghasilkan return yang lebih besar daripada perusahaan yang lain, maka berarti perusahaan tersebut lebih baik dalam memanfaatkan CE-nya. Dengan demikian, pemanfaatan CE yang lebih baik merupakan bagian dari IC perusahaan.

Hubungan selanjutnya adalah VA dan HC. 'Value Added Human Capital' (VAHU) menunjukkan berapa banyak VA dapat dihasilkan dengan dana yang dikeluarkan untuk tenaga kerja. Hubungan antara VA dan HC mengindikasikan kemampuan dari HC untuk menciptakan nilai di dalam perusahaan. Konsisten dengan pandangan para penulis IC lainnya, Pulic berargumen bahwa total salary and wage costs adalah indikator dari HC perusahaan.

Hubungan ketiga adalah "structural capital coefficient" (STVA), yang menunjukkan kontribusi structural capital (SC) dalam penciptaan nilai. STVA mengukur jumlah SC yang dibutuhkan untuk menghasilkan 1 rupiah dari VA dan merupakan indikasi bagaimana keberhasilan SC dalam penciptaan nilai. SC bukanlah ukuran yang independen sebagaimana HC, ia dependen terhadap value creation. Artinya, semakin besar kontribusi HC dalam value creation, maka akan semakin kecil kontribusi SC dalam hal tersebut. Lebih lanjut Pulic menyatakan bahwa SC adalah VA dikurangi HC, yang hal ini telah diverifikasi melalui penelitian empiris pada sektor industri tradisional (Pulic, 2000). Rasio terakhir adalah menghitung kemampuan intelektual perusahaan dengan menjumlahkan koefisien-koefisien yang telah dihitung sebelumnya. Hasil penjumlahan tersebut diformulasikan dalam indikator baru yang unik, yaitu VAIC ${ }^{\text {TM }}$ (Tan et al., 2007: 83).

Keunggulan metode VAIC ${ }^{\text {TM }}$ adalah karena data yang dibutuhkan relatif mudah diperoleh dari berbagai sumber dan jenis perusahaan. Data yang dibutuhkan untuk menghitung berbagai rasio tersebut adalah angka-angka keuangan yang standar yang umumnya 
tersedia dari laporan keuangan perusahaan. Alternatif pengukuran IC lainnya terbatas hanya menghasilkan indikator keuangan dan non-keuangan yang unik yang hanya untuk melengkapi profil suatu perusahaan secara individu. Indikator-indikator tersebut, khususnya indikator non-keuangan, tidak tersedia atau tidak tercatat oleh perusahaan yang lain (Tan et al., 2007;85). Konsekuensinya, kemampuan untuk menerapkan pengukuran IC alternatif tersebut secara konsisten terhadap sample yang besar dan terdiversifikasi menjadi terbatas (Firer dan Williams, 2003;359).

Sejumlah penelitian di berbagai negara telah menggunakan VAIC sebagai proksi atas IC. Mavridis (2004) dan Kamath (2007) misalnya, menggunakan VAIC untuk merangking kinerja IC perbangkan di Jepang dan India. Hal yang sama kemudian dilakukan oleh Ulum (2009a) untuk konteks perbankan yang terdaftar di Bursa Efek Indonesia. Hasilnya menemukan bahwa secara umum, kinerja IC perusahaan perbankan di Indonesia tahun 2004 masuk dalam kategori "top performers" berdasarkan klasifikasi yang dibuat oleh Mavridis (2004) dan Kamath (2007).

Lebih lanjut, VAIC juga banyak digunakan untuk meneliti pengaruh IC terhadap kinerj perusahaan. Firer dan Williams (2003) menguji hubungan VAIC $^{\text {TM }}$ dengan kinerja perusahaan di Afrika Selatan, sementara Chen et al. (2005) menggunakan VAIC ${ }^{\text {тм }}$ untuk menguji hubungan antara IC dengan nilai pasar dan kinerja keuangan perusahaan dengan menggunakan sampel perusahaan publik di Taiwan. Tan et al. (2007) menggunakan 150 perusahaan yang terdaftar di bursa efek Singapore sebagai sampel penelitian untuk melihat pengaruh IC terhadap kinerja keuangan perusahaan.

Di Indonesia, kajian yang sama juga mulai banyak dilakukan. Ulum (2007, 2008a) misalnya menganalisis hubungan antara IC (diproksikan dengan VAIC $^{\mathrm{TM}}$ ) dan kinerja perusahaan perbankan di Indonesia, baik terdaftar maupun tidak terdaftar di BEI. Berdasarkan hasil pengujian dengan PLS diketahui bahwa secara statistik (baik nilai $t$-statistics seluruh path antara VAIC ${ }^{\text {TM }}$ dan PERF maupun nilai $R$-square) terbukti terdapat pengaruh $\mathrm{VAIC}^{\mathrm{TM}}$ terhadap kinerja keuangan perusahaan, baik kinerja masa kini maupun masa yang akan datang. Artinya, IC dapat digunakan untuk memprediksi kinerja perusahaan di masa yang akan datang. 
Ulum (2008b) dalam penelitian berjudul Intellectual Capital dan Return Finansial Perusahaan Publik Sektor Perbankan di Indonesia berusaha menguji kembali daya pengaruh VAIC ${ }^{\mathrm{TM}}$ terhadap kinerja keuangan dengan mengkhususkan pada perusahaan perbankan yang go publik (terdaftar di Bursa Efek Indonesia). Hasilnya konsisten dengan kajian sebelumnya bahwa VAIC ${ }^{\text {TM }}$ berpengaruh terhadap kinerja keuangan.

Dalam perkembangan selanjutnya, Ulum (2012) berusaha menginvestigasi hubungan antara kinerja modal intelektual (VAIC) dan praktik pengungkapannya (IC disclosure) dalam laporan tahunan perusahaan. Hasilnya menemukan indikasi bahwa jika suatu perusahaan memiliki kinerja IC yang baik (VAIC-nya tinggi), ad a kecenderungan untuk meminimalisir jumlah (kuantitas) informasi tentang IC yang diungkapkan dalam laporan tahunan perusahaan. Manajemen mungkin berasumsi bahwa tingginya kinerja IC dapat menjadi sinyal bagi kompetitor tentang kekuatan perusahaan dalam memenangi kompetisi di pasar. Hasil penelitian ini konsisten dengan temuan Williams (2001) yang menggunakan 30 perusahaan publik di Inggris yang masuk dalam kelompok FTSE 100 dalam kurun waktu 1996-2000.

\section{Metode Penelitian}

Jenis penelitian yang digunakan dalam penelitian ini adalah penelitian eksploratif yang ingin menemukan "teori baru" atau mengembangan teori melalui formulasi, pengujian, dan pengembangan ulang preposisi selama penyusunan teori yang bersifat grounded. Penelitian ini berusaha untuk mengkonstruksi suatu metode ukuran kinerja IC untuk perbankan syariah dengan melakukan kajian mendalam terhadap metode Penilaian yang telah ada (VAIC ${ }^{\mathrm{TM}}$ ) dan disesuaikan dengan akun-akun dalam laporan keuangan perbankan syariah.

Unit analisis dalam penelitian ini adalah (1) metode Penilaian kinerja IC yang dikonstruksi oleh Ante Pulic (VAIC ${ }^{\mathrm{TM}}$ ). Metode ini akan dianalisis untuk dilakukan modifikasi; (2) standar akuntansi keuangan syariah yang akan digunakan untuk memodifikasi metode VAIC ${ }^{\text {TM}}$; dan (3) literatur-literatur akuntansi keuangan yang relevan. 
Data yang digunakan adalah data sekunder yang terdiri dari:

1. Data jenis-jenis akun yang digunakan untuk mengkonstruksi metode VAIC ${ }^{\text {тм}}$. Data ini diperoleh dari kajian literatur dan internet.

2. Data jenis-jenis akun dan format pelaporan keuangan perbankan syariah. Data ini dapat diperoleh dari standar akuntansi keuangan (SAK) syariah yang diterbitkan DSAK Syariah Ikatan Akuntan Indonesia (IAI) dan Bank Indonesia.

Tahapan analisis data yang dilakukan adalah sebagai berikut:

1. mengidentifikasi akun-akun dalam perhitungan $\mathrm{VAIC}^{\mathrm{TM}}$-nya Pulic yang sejauh ini digunakan untuk perusahaan konvensional. Hal ini dilakukan oleh tim peneliti melalui sebuah diskusi dengan tim dari Kantor Akuntan Publik yang memiliki keahlian tentang seluk-beluk akun;

2. mengidentifikasi akun-akun yang disajikan dalam laporan keuangan perbankan syariah melalui kajian terhadap SAK Syariah dan peraturan terkait, serta laporan keuangan bank/ unit usaha syariah. Hal ini dilakukan oleh tim peneliti melalui sebuah diskusi dengan tim dari Kantor Akuntan Publik yang memiliki keahlian dalam hal 'mengutak-atik' akun;

3. Melakukan modifikasi dan penyesuaian akun-akun dalam perhitungan VAIC $^{\mathrm{TM}}$ dengan akun-akun dalam laporan keuangan perbankan syariah. Hal ini dilakukan melalui diskusi mendalam dengan para ahli di bidangnya (akademisi dan praktisi perbankan syariah) dalam bentuk Focus Group Discussion (FGD); dan

4. Menyusun metode Penilaian kinerja IC untuk perbankan syariah dengan pendekatan iB-value added intellectual coefficient (iBVAIC).

\section{Analisis}

\section{Gambaran Umum Perbankan Syariah}

Perkembangan perbankan syariah selama satu tahun terakhir, sampai dengan bulan Oktober 2012 (yoy) cukup menggembirakan. Perbankan syariah mampu tumbuh $\pm 37 \%$ sehingga total asetnya menjadi Rp174,09 triliun. Pembiayaan telah mencapai Rp135,58 
triliun (40,06\%, yoy) dan penghimpunan dana menjadi Rp134,45 triliun $(32,06 \%)$.

Pertumbuhan penghimpunan dana cukup baik diimbangi dengan pertumbuhan penyaluran dana kepada sektor riil baik berupa pembiayaan (Mudharabah dan Musyarakah), piutang (Murabahah, Istisna, dan Qardh), dan dalam bentuk pembiayaan Ijarah. Dengan demikian fungsi intermediasi perbankan dapat relatif terjaga yang tercermin dari FDR agregat perbankan syariah tercatat cukup tinggi yaitu sebesar 100,84\% meningkat lebih tinggi dari tahun sebelumnya yang tercatat sebesar 95,08\%. Selain fungsi intermediasi, untuk memberikan pelayanan dengan jangkauan yang lebih luas bagi masyarakat, akses jaringan perkantoran meningkat menjadi 2.188 (29,31\%) dari 1.692 kantor pada tahun sebelumnya. Perluasan jaringan kantor tersebut telah mampu meningkatkan pengguna bank syariah yang tercermin dari peningkatan jumlah total rekening (pembiayaan + DPK) yaitu sebesar 3,4 juta rekening dari 9 juta rekening menjadi 12,4 juta rekening (Oktober 2012, yoy).

Selama periode tahun 2012, jumlah Bank Umum Syariah (BUS) dan Unit Usaha Syariah (UUS) sampai dengan Oktober 2012 tidak mengalami perubahan, namun demikian jumlah jaringan kantor meningkat. Meskipun dengan jumlah BUS (11 buah) maupun UUS ( 24 buah) yang sama, namun pelayanan kebutuhan masyarakat akan perbankan syariah menjadi semakin meluas yang tercermin dari bertambahnya Kantor Cabang dari sebelumnya sebanyak 452 menjadi 508 Kantor, sementara Kantor Cabang Pembantu (KCP) dan Kantor Kas (KK) telah bertambah sebanyak 440 kantor pada periode yang sama (Oktober 2012, yoy). Secara keseluruhan jumlah kantor perbankan syariah yang beroperasi sampai dengan bulan Oktober 2012 dibandingkan tahun sebelumnya meningkat dari 1.692 kantor menjadi 2.188 kantor.

BPRS sebagai bagian dari lembaga perbankan syariah juga mengalami perkembangan yang cukup menggembirakan. Aset BPRS selama kurun waktu satu tahun terakhir meningkat sebesar 33,09\% menjadi sebesar Rp4,46 triliun (yoy), dengan share pembiayaan merupakan 77,68\% dari total aktiva. Penghimpunan dana BPRS juga meningkat tinggi yaitu sebesar 41,47\% menjadi Rp2,77 triliun. 
BPRS telah menjalankan fungsi intermediasi perbankan dengan baik, tercermin dari rasio FDR agregat BPRS yang mencapai 124,80\%. Pertumbuhan penyaluran dana tersebut cukup terkendali dengan kualitas pembiayaan yang baik dengan penurunan rasio NPF (net) dari 5,90\% menjadi 5,60\%. Rasio permodalan BPRS cukup memadai yang tercermin dari agregat rasio CAR yang tinggi mencapai $25 \%$.

Keunggulan karakteristik BPRS yang beroperasi di daerahdaerah terpencil bahkan sampai pada daerah remote area sehingga dapat memberikan pelayanan dengan jangkauan yang lebih luas kepada masyarakat. Luasnya demografi BPRS ternyata berperan cukup signifikan dalam perolehan laba untuk menjaga tingkat rentabilitas. Rasio ROE meningkat dari $16,10 \%$ menjadi $22,30 \%$, ROA meningkat dari 2,40\% menjadi 2,80\%, meskipun rasio BOPO lebih tinggi dari rata-rata BUS dan UUS, namun dapat dijaga dalam kisaran $86,20 \%$.

\section{Menghitung iB-Value Added (VA)}

Menggunakan data laporan keuangan, standar pelaporan, dan regulasi terkait tentang perbankan syariah, kami mengidentikasi akun-akun dalam laporan keuangan bank syariah untuk menyusun model iB-VAIC. Berdasarkan hasil focus grup discussion (FGD) yang telah dilakukan, maka rumus yang digunakan untuk menghitung iB-VAIC adalah sebagai berikut:

Tahap pertama dengan menghitung iB-Value Added (iB-VA). IB-VA dihitung dengan menggunakan cara yaitu sebagai berikut :

$$
\mathrm{iB}-\mathrm{VA}=\mathrm{OUT}-\mathrm{IN}
$$

OUT (Output) : Total pendapatan, diperoleh dari:

1. Pendapatan bersih kegiatan syariah = pendapatan operasi utama kegiatan syariah + pendapatan operasi lainnya - hak pihak ketiga atas bagi hasil dan syirkah temporer. Pendapatan operasi utama kegiatan syariah terdiri:

a. Pendapatan penyaluran dana

1) Dari pihak ketiga bukan bank

a) Pendapatan dari jual beli (pendapatan marjin murabahah) 
b) Pendapatan bersih salam parallel

c) Pendapatan bersih istishna parallel

d) Pendapatan sewa ijarah

e) Pendapatan pendapatan bagi hasil musyarakah

f) Pendapatan bagi hasil mudharabah

g) Pendapatan dari penyertaan

h) lainnya

2) Dari Bank Indonesia

a. Bonus SBIS

b. Lainnya

3) Dari bank-bank lain di Indonesia

a. Bonus dari bank syariah lain

b. Pendapatan bagi hasil mudharabah

c. Tabungan mudharabah

d. Deposito mudharabah

e. Sertifikat investasi mudharabah antar bank

f. Lainnya

b. Pendapatan operasi lainnya

1) Jasa investasi terikat (mudharabah muqayyadah)

2) Jasa layanan

3) Pendapatan dari transaksi valuta asing

4) Koreksi PPAP

5) Koreksi penyisihan penghapusan transaksi rek. Administrasi

6) Lainnya

c. Hak pihak ketiga atas bagi hasil syirkah temporer

1) Pihak ketiga bukan bank

a. Tabungan mudharabah

b. Deposito mudharabah

c. Lainnya

2) Bank Indonesia 

a) FPJP syariah
b) Lainnya

3) Bank-bank lain di Indonesia dan di luar Indonesia

a) Tabungan mudharabah

b) Deposito mudharabah

c) Sertifikat investasi mudharabah antar bank

d) Lainnya

2. Pendapatan non operasional

IN (input): Beban usaha/operasional dan beban non operasional kecuali beban kepegawaian/karyawan

Beban usaha/operasional kecuali beban kepegawaian:

a. Beban penyisihan kerugian asset produktif-bersih

b. Beban estimasi kerugian komitmen dan kontijensi

c. Beban operasi lainnya

d. Beban bonus titipan wadiah

e. Beban administrasi dan umum

f. Beban penurunan nilai surat nerharga

g. Beban transaksi valuta asing

h. Beban promosi

i. Beban lainnya

Value added (iB-VA) juga dapat dihitung dari akun-akun perusahaan sebagai berikut:

$$
\mathrm{iB}-\mathrm{VA}=\mathrm{OP}+\mathrm{EC}+\mathrm{D}+\mathrm{A}
$$

Keterangan:

OP: operating profit (laba operasi/laba usaha)

EC : employee costs (beban karyawan)

$\mathrm{D}$ : depreciation (depresiasi)

A : amortization (amortisasi) 
Menghitung iB-Value Added Capital Employed (iB-VACA)

Tahap kedua dengan menghitung Value Added Capital Employed (iB-VACA). iB-VACA adalah indikator untuk iB-VA yang diciptakan oleh satu unit dari human capital. Rasio ini menunjukkan kontibusi yang dibuat oleh setiap unit dari CE terhadap value added perusahaan.

$$
\mathrm{iB}-\mathrm{VACA}=\frac{\boldsymbol{V} \boldsymbol{A}}{\boldsymbol{C E}} \frac{\boldsymbol{V A}}{\boldsymbol{C E}}
$$

Keterangan:

iB-VACA : Value Added Capital Employed : rasio dari iB-VA terhadap CE

$\mathrm{iB}-\mathrm{VA}$ : value added

CE : Capital Employed: dana yang tersedia (total ekuitas)

Menghitung iB-Value Added Human Capital (iB-VAHU)

iB-VAHU menunjukkan berapa banyak iB-VA dapat dihasilkan dengan dana yang dikeluarkan untuk tenaga kerja. Rasio ini menunjukkan kontribusi yang dibuat oleh setiap rupiah yang diinvestasikan dalam HC terhadap value added organisasi.

$$
\mathrm{iB}-\mathrm{VAHU}=\frac{\boldsymbol{V A V A}}{\boldsymbol{H C H C}}
$$

Keterangan :

iB-VAHU: Value added Human Capital : rasio dari iB-VA terhadap $\mathrm{HC}$

iB-VA : Value added

HC : Human capital : beban karyawan

Menghitung Structural Capital Value Added (iB-STVA)

Rasio ini mengukur jumlah SC yang dibutuhkan untuk menghasilkan satu rupiah dari iB-VA dan merupakan indikasi bagaimana keberhasilan SC dalam penciptaan nilai. 


$$
\text { iB-STVA }=\frac{S C S C}{V A V A}
$$

Keterangan :

STVA : Structural Capital Value Added : rasio dari SC terhadap IB-VA

SC : Structural capital : IB-VA - HC

IB-VA : Value Added

Menghitung Value Added Intellectual Coefficient (iB-VAIC ${ }^{\mathrm{TM}}$ )

IB-VAIC $^{\mathrm{TM}}$ mengindikasikan kemampuan intelektual organisasi yang dapat juga dianggap sebagai BPI (Business Performance Indikator). $\mathrm{iB}^{\mathrm{V}} \mathrm{VAIC}^{\mathrm{TM}}$ merupakan penjumlahan dari tiga komponen sebelumnya, yaitu iB-VACA, iB-VAHU, dan iB-STVA.

$$
i B-V A I C{ }^{\text {TM }}=i B-V A C A+I B-V A H U+i B-S T V A
$$

iB-VAIC yang dirumuskan dalam penelitian ini dapat digunakan untuk mengukur kinerja IC perbankan syariah di Indonesia. Perhitungan yang berbasis pada akun-akun dalam laporan keungan tradisional ini akan dengan mudah dapat dilakukan dan dapat memberikan gambaran tentang kinerja IC yang dimiliki oleh perbankan syariah.

Untuk dapat dilakukan pemeringkatan terhadap sejumlah perbankan, hasil perhitungan iB-VAIC (untuk selanjutnya dapat disebut BPI) dapat diranking berdasarkan skor yang dimiliki. Sejauh ini, belum ada standar tentang skor kinerja IC tersebut, namun penelitian Ulum (2008) telah merumuskan untuk memberikan kategori dari hasil perhitungan VAIC, yaitu:

1. Top performers - skor VAIC ${ }^{\mathrm{TM}}$ di atas 3,00

2. Good performers - skor VAIC ${ }^{\mathrm{TM}}$ antara 2,0 sampai 2,99

3. Common performers - skor VAIC ${ }^{\mathrm{TM}}$ antara 1,5 sampai 1,99

4. Bad performers - skor VAIC ${ }^{\mathrm{TM}}$ di bawah 1,5 


\section{Kesimpulan}

Formula perhitungan iB-VAIC pada dasarnya tidak banyak berbeda dengan formula VAIC ${ }^{\mathrm{TM}}$ yang dirumuskan oleh Pulic (1998). Perbedaan mendasar diantara keduanya terletak pada akun-akun untuk menghitung VA.

Dalam iB-VAIC, VA dikonstruksi dari akun-akun pendapatan yang semuanya adalah berbasis syariah, yaitu pendapatan bersih kegiatan syariah dan pendapatan non-operasional yang syar'iy. Formula akhir dalam menghitung iB-VAIC adalah sebagai berikut:

$$
i B-V^{2} I^{\mathrm{TM}}=i B-V A C A+I B-V A H U+i B-S T V A
$$

Dengan menggunakan formula ini, kinerja IC perbankan syariah dapat diukur. Hasil pengukuran tersebut dapat menjadi indikasi bagi pengambil keputusan tentang bagaimana perusahaan mengelola IC yang dimiliki untuk memaksimalkan value bagi perusahaan.

\section{Daftar Pustaka}

Ahmad, S. \& A.M. Mushraf. 2011. "The Relationship between Intellectual Capital and Business Performance: An Empirical Study in Iraqi Industry". Conference Proceeding 2011 International Conference on Management and Artificial Intelligence. Bali, Indonesia.

Bontis, N. 1998. "Intellectual Capital: an Exploratory Study that Develops Measures and Models". Management Decision. Vol. 36 No. 2. p. 63.

Bontis, N., W.C.C. Keow, S. Richardson. 2000. "Intellectual Capital and Business Performance in Malaysian Industries". Journal of Intellectual Capital. Vol. 1 No. 1. pp. 85-100.

Brooking, A. 1996. Intellectual Capital: Core Asset for Third Millennium Enterprise. International Thomson Business Press, London.

Chen, M.C., S.J. Cheng, Y. Hwang. 2005. "An Empirical Investigation of the Relationship between Intellectual Capital and Firms' Market Value and Financial performance". Journal of 
Intellectual Capital. Vol. 6 N0. 2. pp. 159-176.

Firer, S., and S.M. Williams. 2003. "Intellectual Capital and Traditional Measures of Corporate Performance". Journal of Intellectual Capital. Vol. 4 No. 3. pp. 348-360.

IFAC. 1998. "The Measurement and Management of Intellectual Capital". Available from www.ifac.org (cited November 2012)

Kamal, M.H.M., R.C. Mat, N.A. Rahim, N. Husin \& I. Ismail. 2011. "Intellectual Capital and Firm Performance of Commercial Banks in Malaysia". Asian Economic and Finance Review. Vol 2/4 pp. 577-590

Kamath, G.B. 2007. "The Intellectual Capital Performance of Indian Banking Sector". Journal of Intellectual Capital. Vol. 8 No. 1. pp. 96-123.

Kubo, I., and A. Saka. 2002. "An inquairy into the motivations of knowledge workers in the Japanese financial industry". Journal of Knowledge Management. Vol. 6 No. 3. pp. 262-271.

Latif, M., M.S. Malik \& S. Aslam. 2012. "Intellectual Capital Efficiency And Corporate Performance In Developing Countries: A Comparison Between Islamic And Conventional Banks Of Pakistan" Interdisciplinary Journal of Contemporary Research in Business. Vol 4/11 pp. 405-420.

Mavridis, D.G. 2004. "The intellectual capital performance of the Japanese banking sector". Journal of Intellectual Capital. Vol. 5 No. 3. pp. 92-115.

Petty, R. and J. Guthrie. .2000. "Intellectual capital literature review: measurement, reporting and management". Journal of Intellectual Capital, Vol. 1 No. 2/3, pp. 155-76.

Pulic, A. 2000. "Basic Information on VAIC"M". available online at: www.vaic-on.net. (accessed November 2006).

Roos, J., G. Roos, N.C. Dragonetti, and L. Edvinsson. 1997. Intellectual Capital: Navigating in the New Business Landscape. Macmillan Business, Houndsmills.

Salman, R.T., M. Mansor \& A.D. Babatunde. 2012. "Impact of Intellectual Capital on Return on Asset in Nigerian 
Manufacturing Companies". Interdisciplinary Journal of Research in Business. Vol 2/4 pp 21-30

Ståhle, P., S. Ståhle \& S. Aho. 2011. "Value Added Intellectual Coefficient (VAIC): a Critical Analysis". Journal of Intellectual Capital. Vol 12/4 pp. 531-551.

Stewart, T.A. (1997) Intellectual Capital: The New Wealth of Organizations, Doubleday/Currency, New York: United States of America.

Tan, H.P., D. Plowman, P. Hancock. 2007. "Intellectual Capital and Financial Returns of Companies. Journal of Intellectual Capital. Vol. 8 No. 1. pp. 76-95.

Ulum, I. 2007. "Pengaruh Intellectual Capital terhadap Kinerja Keuangan Perusahaan Publik Sektor Perbankan". Thesis magister akuntansi Undip, unpublished.

. 2008a. "Intellectual Capital dan Kinerja Keuangan Perusahaan; Sebuah Analisis dengan Pendekatan Partial Least Squares". Call for paper Simposium Nasional Akuntansi XI. Ikatan Akuntan Indonesia. Pontianak. . 2008b. Intellectual Capital and Financial Return of Listed Indonesian Banking Sector. Proceeding international research seminar and exhibition. Lemlit UMM. Malang.

. 2009a. "Intellectual Capital Performance Sektor Perbankan di Indonesia". Jurnal Akuntansi dan Keuangan (terakreditasi dikti). Vol 10/2. Februari 2009. ISSN: 1411-0288.

2009b. Intellectual Capital; Konsep dan Kajian Empiris.

PT. Graha Ilmu, Yogyakarta.

. 2009c. Investigasi Hubungan antara Intellectual Capital dan Nilai Pasar Perusahaan serta Kinerja Keuangan. Program Penelitian Unggulan FE UMM, Malang.

2012. "Investigasi Hubungan antara Modal Intelektual dan Praktik Pengungkapannya (IC Disclosure) dalam Laporan Tahunan Perusahaan". Jurnal Ekonomi Bisnis. Tahun 17 No. 1, pp 36-45. 
Wang, M.S. 2011. "Intellectual Capital and Firm Performance". Proceeding Annual Conference on Innovations in Business $\&$ Management. London, The Center for Innovations in Business and Management Practice. 